Vol. I No.2 Juni 2018

http://joernal.umsb.ac.id/index.php/RANGTEKNIKJOURNAL

\title{
Sistem Informasi Pemasaran Perumahan Dan Pembayaran Konsumen Pada Cv Mandiri Utama Cabang Payakumbuh Menggunakan Visual Basic 6.0
}

\author{
Sri Tria Siska \\ Email : siska6830@gmail.com \\ Dosen Tetap Prodi Teknik Komputer \\ Sekolah Tinggi Teknologi Payakumbuh, Jl. Khatib Sulaiman, Sawah Padang
}

\begin{abstract}
Abstrak: Penelitian yang dilakukan pada CV Mandiri Utama bertujuan untuk membangun sebuah Sistem Informasi dengan menggunakan bahasa pemograman Visual Basic 6.0 untuk membantu dalam proses pembayaran konsumen dan merancang suatu database yang dapat menyimpan data-data yang berkaitan dengan analisis laporan data pembayaran konsumen dari sistem tersebut, serta mempermudah proses dan penyajian informasi yang akurat mengenai proses pembayaran. Metode penelitian yang penulis gunakan adalah metode wawancara dan observasi.
\end{abstract}

Kata Kunci : pembayaran,vb6.0 visual basic

\section{PENDAHULUAN}

Dalam era globalisasi saat ini perkembangan ilmu pengetahuan dan teknologi terus maju dengan pesat. Hal ini mendorong berbagai perubahan yang sangat cepat dalam segi kehidupan dan tidak dipungkiri lagi perubahanperubahan tersebut terasa dalam kehidupan sehari-hari. Salah satu hasil pemanfaatan kemajuan teknologi adalah pengggunaan komputer, yang pada masa sekarang maupun masa akan datang akan sangat dibutuhkan, karena telah terbukti bahwa komputer merupakan alat bantu dalam menyelesaikan pekerjaan manusia secara akurat, efektif, dan efisien. Komputer memiliki peranan yang sangat penting dalam pencapaian tujuan perusahaan tersebut. Dengan adanya komputer mampu meningkatkan kinerja CV.Mandiri Utama.

Untuk itu perlu dibangun sebuah sistem informasi dan sebuah database yang dapat menampung data dalam jumlah banyak sehingga apabila dilakukan pengaksesan terhadap suatu data akan lebih mudah untuk mendapatkannya dan juga mudah melakukan perhitungan dalam jumlah banyak sehingga informasi yang diperoleh lebih baik dan cepat. Akan tetapi, dalam pembayaran perumahan pada Kantor CV.Mandiri Utama Cabang Payakumbuh belum menggunakan komputerisasi yang artinya belum memanfaatkan teknologi komputer secara optimal khususnya dalam pembayaran perumahan tersebut. Sehingga memungkinkan terjadinya kesalahan dalam perhitungan yang dapat mengakibatkan kerugian terhadap CV.Mandiri Utama tersebut.
Sehubungan dengan hal diatas maka penulis berusaha untuk melakukan implementasi sistem guna mencapai berbagai peningkatan dalam pengolahan data dengan mendesain sebuah sistem yang dituangkan dalam bentuk penelitian dengan judul "SISTEM INFORMASI PEMASARAN PERUMAHAN DAN PEMBAYARAN KONSUMEN PADA CV MANDIRI UTAMA CABANG PAYAKUMBUH VISUAL BASIC 6.0" MENGGUNAKAN

\subsection{Perumusan Masalah}

Dari latar belakang diatas dapat dikemukakan beberapa permasalahan permasalahan yang terdapat dalam pemasaran perumahan dan pembayaran konsumen pada CV.Mandiri Utama yaitu :

1. Bagaimana sistem informasi pemasaran dan pembayaran konsumen ini dapat mempermudah bagian administrasi dalam melakukan perhitungan biaya pembayaran konsumen secara transparan?

2. Bagaimana dengan adanya sistem informasi pemasaran dan pembayaran konsumen dapat mempermudah bagian administrasi dalam pembuatan laporan pengkreditan?

3. Bagaimana sistem informasi pemasaran dan pembayaran konsumen dapat bekerja secara efisien bagi pimpinan dalam pengambilan keputusan?

\subsection{Tujuan Penelitian}

Adapun tujuan utama dari penulisan ISSN 2599-2081 yang dilakukan ini adalah untuk 
mengembangkan suatu sistem yang baru, dengan tidak lepas dari penyempurnaan sistem yang lama dan mengarah ke sistem komputerisasi secara lengkap dapat diuraikan sebagai berikut :

1. Untuk mengetahui kelemahan dan kekurangan sistem yang sedang berjalan sehingga dapat mengatasi kendala-kendala yang terjadi selama ini.

2. Berusaha menciptakan suatu sistem kerja yang lebih baik sehingga dapat meningkatkan efisiensi kerja dan mengoptimalkan sarana dan prasarana yang ada.

3. Untuk mengetahui manfaat dan kemampuan sistem komputer dalam menyelesaikan sistem informasi pengolahan data perumahan pada CV.Mandiri Utama dalam penyajian informasi yang lebih baik sehingga memudahkan penyusunan laporan yang dibutuhkan oleh pimpinan.

4. Menganalisa kelemahan dari sistem lama yang nantinya akan dibuat sebuah sistem baru yang dapat mengatasi atau menutupi kelemahan - kelemahan dari sistem lama tersebut.

\subsection{Ruang Lingkup Penelitian}

Supaya penulis laporan studi akhir ini terarah dari pemasalahan yang dihadapi dan tidak menyimpang, maka penulis memberikan batasan penelitian khusus terhadap masalah sistem pengolahan data perumahan yang dihasilkan oleh CV.Mandiri Utama Cabang Payakumbuh.

\section{LANDASAN TEORI}

\subsection{Pengertian Sistem}

Menurut Jogiyanto (2008:34) mendefinisikan "Sistem dapat didefinisikan dengan pendekatan prosedur dan pendekatan komponen".

\subsection{Pengertian Informasi}

Menurut Jogiyanto (2008:36) mendefinisikan "Informasi adalah data yang diolah menjadi bentuk yang berguna bagi para pemakainya."

\subsection{Pengertian Sistem Informasi}

Pengertian sistem informasi menurut Tata Subatri Tahun 2008 mengemukakan

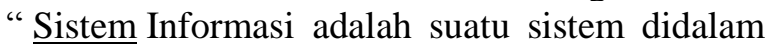
organisasi yang mempertemukan kebutuhan pengelolah transaksi harian, mendukung operasi, bersifat manajerial dan kegiatan strategi dari suatu organisasi dan menyediakan pihak luar tertentu dengan laporan-laporan yang diperlukan."

\subsection{Sekilas Tentang Visual Basic}

Microsoft Visual Basic merupakan sebuah pemrograman komputer yang berjalan pada sistem operasi Windows. Bahasa Pemrograman adalah sekumpulan perintah atau intruksi yang dimengerti oleh komputer untuk mengerjakan tugas - tugas tertentu.

Microsoft Visual Basic selain disebut sebagai sarana Bahasa Pemrograman (language program), juga sering disebut juga sarana (tool) untuk menghasilkan program program aplikasi berbasis windows.

\subsection{Sekilas Tentang MySQL}

MySQL adalah Relational Database Management Sistem (RDBMS) yang didistribusikan secara gratis di bawah licensi GPL (General Public License). Dimana setiap orang bebas untuk menggunakan MySQL, namun tidak boleh dijadikan produk turunan yang bersifat close source atau komersial.

\section{ANALISA DAN HASIL}

\subsection{Aliran Sistem Yang Sedang Berjalan}

Aliran sistem informasi merupakan suatu alat yang dapat menjelaskan urutan pekerjaan dalam penerapan sistem ini, aliran ini akan memudahkan bagi orang yang bersangkutan untuk memahami dan mengerti bagaimana sistem ini bekerja.

Adapun aliran sistem informasi pembayaran rumah pada CV Mandiri Utama sebagai berikut :

1. Pembeli memperoleh surat permohonan dari bagian administrasi, dimana surat tersebut diisi dan diserahkan lagi kepada bagian administrasi.

2. Bagian administrasi akan memeriksa surat permohonan untuk diserahkan kepada Bank untuk memperoleh kredit dari Bank.

3. Bank akan melakukan studi kelayakan, apabila disetujui oleh pihak Bank. Lalu bank akan menyerahkan surat permohonan yang telah disetujui ke bagian administrasi.

4. Bagian administrasi akan membuat surat persetujuan pembelian rumah secara kredit yang akan menghasilkan surat persetujuan pembelian rumah sebanyak tiga rangkap, dimana satu rangkap diserahkan kepada pembeli, satu rangkap diarsipkan dan satu rangkap lagi diserahkan kepada pimpinan.

$\begin{array}{lr}\text { Fakultas Teknik UMSB } & \text { ISSN 2599-2081 } \\ & \text { EISSN 2599-2090 }\end{array}$


5. Selanjutnya pembeli melakukan pembayaran kredit melalui bank, pembeli datang ke bank dan megisi slip setoran kredit rumah sebanyak tiga rangkap yang telah disediakan oleh pihak bank

6. Piihak bank akan memeriksa dan menerima pembayaran kredit, lalu satu rangkap dari slip setoran akan diserahkan lagi kepada pembeli, satu rangkap akan diserahkan kepada bagian administrasi dan satu rangkap diarsipkan oleh pihak bank

7. Berdasarkan slip setoran yang diterima dari pihak bank, lalu administrasi akan membuat laporan setoran kredit rumah sebanyak dua rangkap, dimana satu rangkap diserahkan kepada pimpinan dan satu rangkap diserahkan kepada pimpinan.

Untuk lebih jelasnya aliran sistem informasi data pembayaran rumah pada CV Mandiri Utama dapat dilihat pada gambar 3.1.

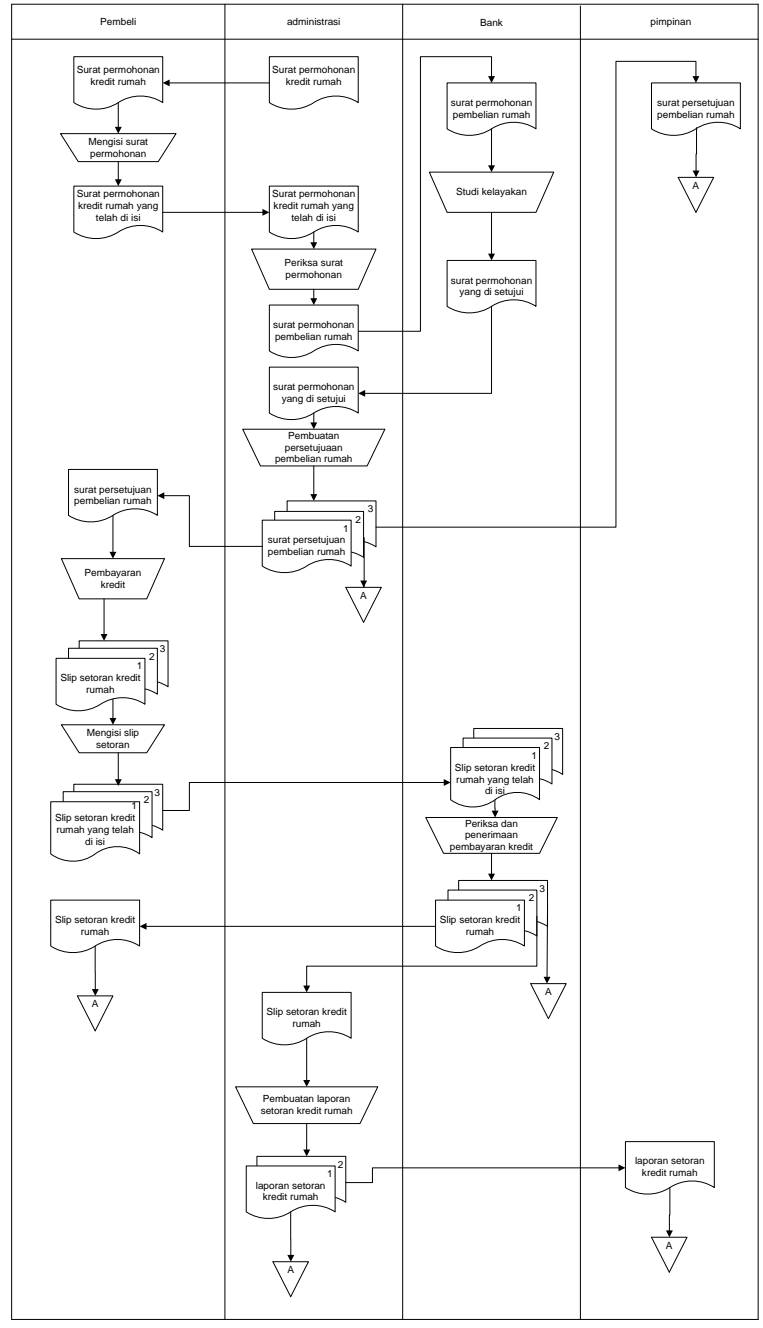

Gambar 3.1 : Aliran sistem informasi Lama

\subsection{Disain Sistem Secara Global}

Disain sistem secara global merupakan suatu langkah dalam perancangan sistem baru. Dalam merancang sistem terlebih dahulu dijabarkan secara garis besarnya saja setelah itu baru dilakukan perancangan sistem secara terinci.

\subsubsection{Aliran Sistem Informasi Baru}

Adapun aliran sistem informasi pembayaran rumah pada CV Mandiri Utama sebagai berikut :

1. embeli memperoleh surat permohonan dari bagian administrasi, dimana surat tersebut di isi dan diserahkan lagi kepada bagian administrasi.

2. Bagian administrasi akan memeriksa surat permohonan untuk diserahkan kepada Bank untuk memperoleh kredit dari Bank.

3. Bank akan melakukan studi kelayakan, apabila disetujui oleh pihak Bank. Lalu bank akan menyerahkan surat permohonan yang telah disetujui ke bagian administrasi.

4. Bagian administrasi akan melakukan pengentrian data pembelian rumah yang akan menghasilkan laporan data rumah, laporan data pembeli dan surat persetujuan pembelian rumah sebanyak dua rangkap, dimana satu rangkap masing-masing laporan akan diserahkan kepada pimpinan dan satu rangkap akan diarsipkan, sedangkan surat persetujuan pembelian rumah sebayak tiga rangkap, dima satu rangkap akan diserahkan kepada pembeli, satu rangkap diserahkan kepada pimpinan dan satu rangkap lagi diarsipkan.

5. Selanjutnya pembeli melakukan pembayaran kredit melalui bank, pembeli datang ke bank dan mengisi slip setoran kredit rumah sebanyak tiga rangkap yang telah disediakan oleh pihak bank

6. Piihak bank akan memeriksa dan menerima pembayaran kredit, lalu satu rangkap dari slip setoran akan diserahkan lagi kepada pembeli, satu rangkap akan diserahkan kepada bagian administrasi dan satu rangkap diarsipkan oleh pihak bank.

7. Berdasarkan slip setoran yang diterima dari pihak bank, lalu administrasi akan melakukan pengentrian data angsuran kredit rumah yang akan menghasilkan laporan data angsuran kredit rumah sebanyak dua rangkap, dimana satu rangkap diserahkan 
kepada pimpinan dan satu rangkap diserahkan kepada pimpinan.

Untuk lebih jelasnya aliran sistem informasi data pembayaran rumah pada CV Mandiri Utama dapat dilihat pada gambar 3.2 berikut:

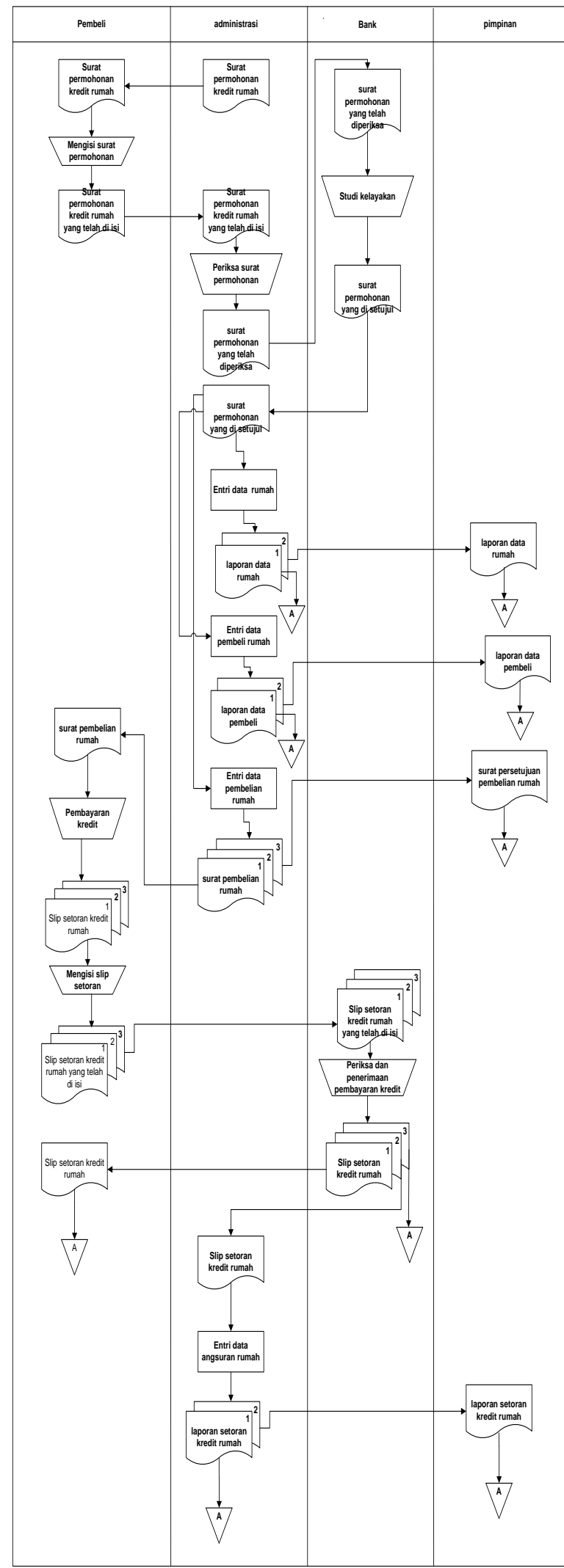

Gambar 3.4 : Aliran sistem informasi Baru

\subsubsection{Contex Diagram}

Context Diagram adalah sebuah gambaran dari sistem organisasi yang 
menampilkan atau memperlihatkan batasanbatasan dari suatu sistem, entity-entity yang berintegrasi dengan sistem dan informasi secara umum yang mengalir diantara entity dari sistem.

Berikut adalah context diagram sistem informasi pembayaran rumah.

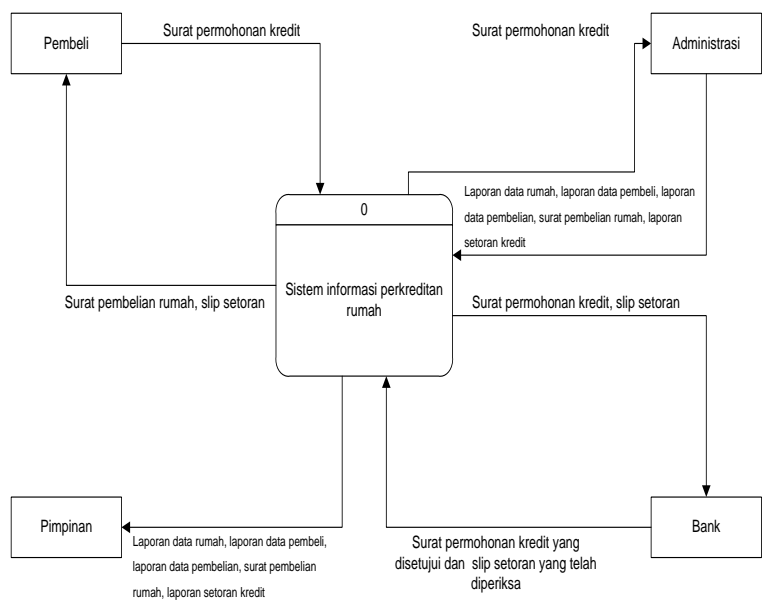

Gambar 3.5 : Context diagram

\subsubsection{Data Flow Diagram Level 0}

Untuk lebih rinci mengenai rancangan sistem baru perlu dibuatkan suatu data flow diagram yang merupakan penguraian dari proses utama yang tertera pada context diagram yang telah dibuat sebelumnya. Berikut ini adalah data flow diagram dari sistem pembayaran rumah.

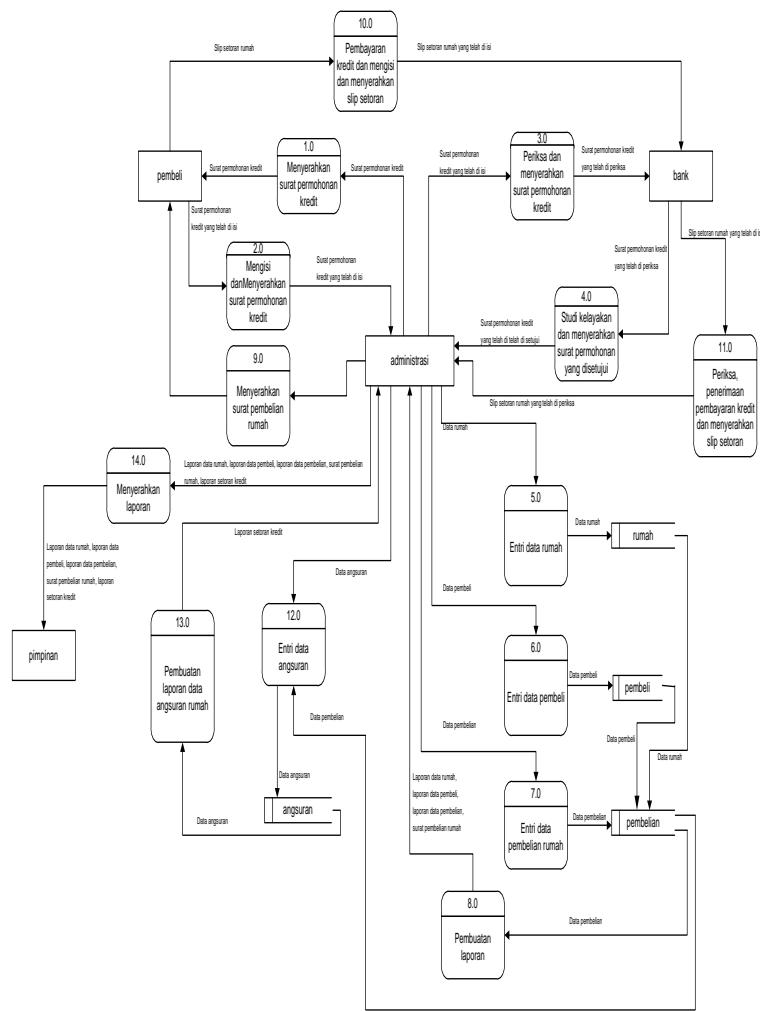

Gambar 3.6 Data Flow Diagram level 0

\subsubsection{Entity Relationship Diagram}

Entity relasionship diagram (ERD) menggambarkan hubungan atau realisasi yang digunakan sistem yang dibuat. Bentuk dari Entity relasionship diagram (ERD) permasalahan yang dapat terlihat pada gambar sebagai berikut :

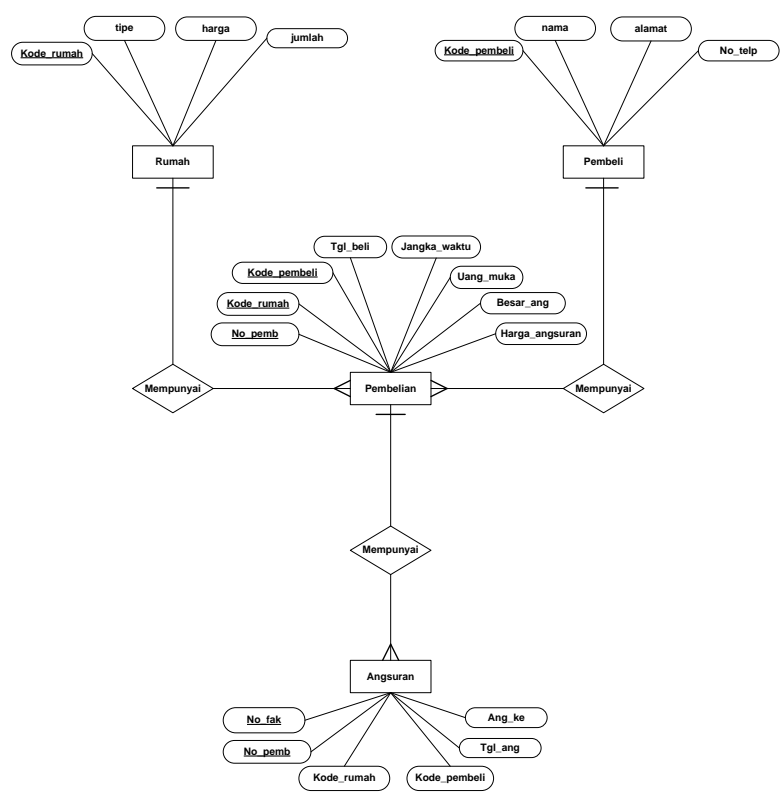

Gambar 3.7 Entity Relationship Diagram (ERD) 


\subsubsection{Struktur Program}

Struktur program merupakan tampilan dari layar yang menunjukkan bagian-bagian dari program yang dikerjakan. Adapun struktur program yang dirancang seperti dibawah ini.

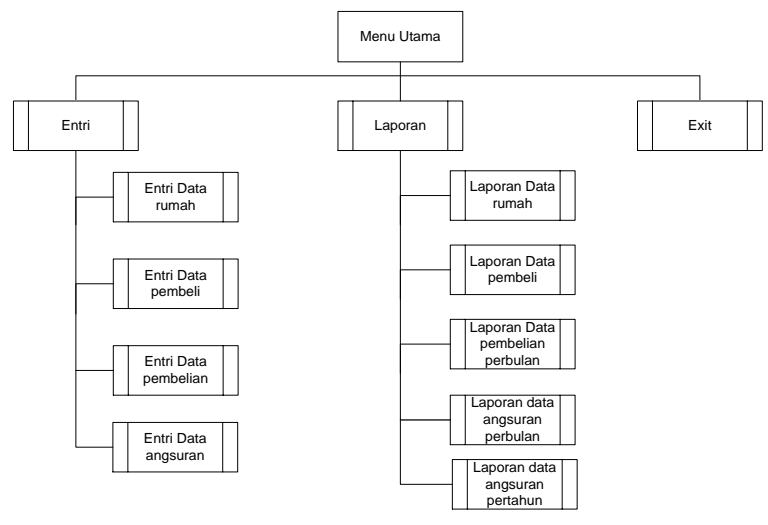

Gambar 3.8 Struktur program

\section{IMPEMENTASI SISTEM}

\subsection{Implementasi}

\subsection{Data Login User}

Sebelum mengakses program menu utama user diminta untuk melakukan login berdasarkan User id pada form data login user. Form ini dirancang untuk meningkatkan keamanan data agar tidak diakses oleh user yang tidak memiliki kepentingan. Bentuk data login user dapat dilihat pada gambar 4.28 berikut:

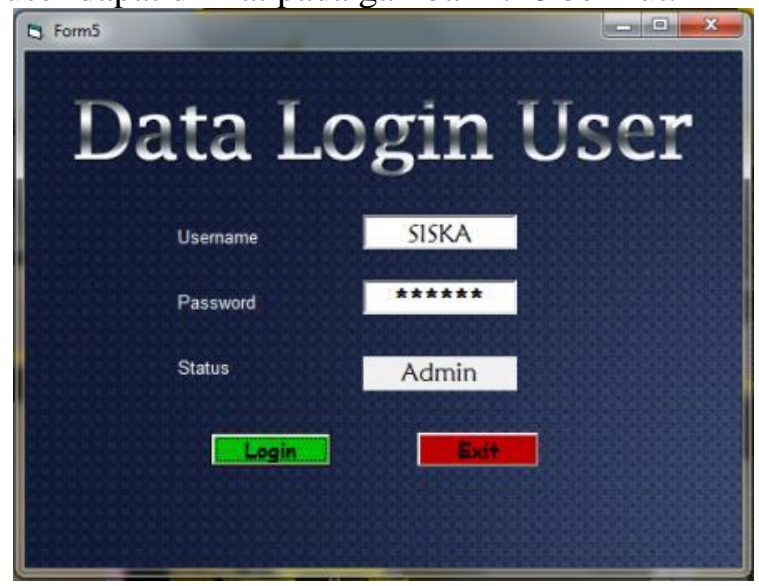

Gambar 4.28 Data Login User

\subsubsection{Program Menu Utama}

Program menu utama merupakan form aplikasi yang terdiri dari sub-sub menu, diantaranya menu entry dan menu laporan. Menu entry pada Sistem Informasi pembayaran perumahan terdiri dari Entry Data Rumah, Entry Data Pembeli, Entry Data Pembelian dan Entry
Data Angsuran sedangkan menu laporan terdiri dari Laporan Data Rumah, Laporan Data Pembeli, Laporan Data Pembelian, Laporan Data Angsuran Perbulan dan Laporan Data Angsuran Pertahun. Bentuk program menu utama dapat dilihat pada gambar 4.29 berikut:

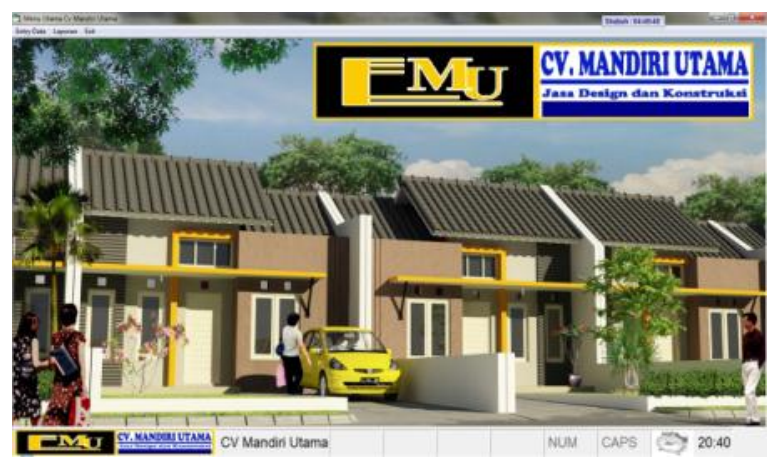

Gambar 4.29 Program Menu Utama

\subsubsection{Program Entry}

Pada progarm entry ada 4 (empat) entry, yaitu:

1. Entry Data Rumah

Form entry data rumah digunakan untuk mengentrikan data rumah yang ada pada $\mathrm{CV}$ Mandiri Utama. Form entry data rumah menyediakan kolom - kolom yang digunakan sebagai tempat melakukan entry data rumah. Form entry data rumah menyediakan beberapa proses yaitu proses penambahan data rumah, proses pengubahan data rumah, proses penghapusan data rumah, dan proses pencarian data rumah. Bentuk form entry data rumah dapat dilihat pada gambar 4.30 berikut.

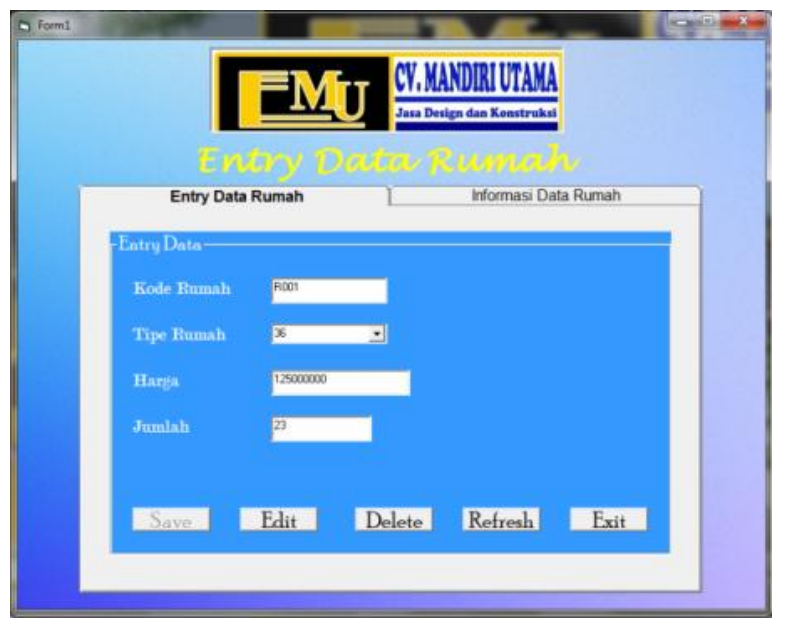

Gambar 4.30 Form Entry Data Rumah

\section{Entry Data Pembeli}

Form entry data pembeli digunakan untuk mengentrikan data pembeli yang ada pada

274 Fakultas Teknik UMSB ISSN 2599-2081


CV Mandiri Utama. Form entry data pembeli menyediakan kolom - kolom yang digunakan sebagai tempat melakukan entry data pembeli. Form entry data penimbangan menyediakan beberapa proses yaitu proses penambahan data pembeli, proses pengubahan data pembeli, proses penghapusan data pembeli, dan proses pencarian data pembeli. Bentuk form entry data pembeli, dapat dilihat pada gambar 4.31 berikut:

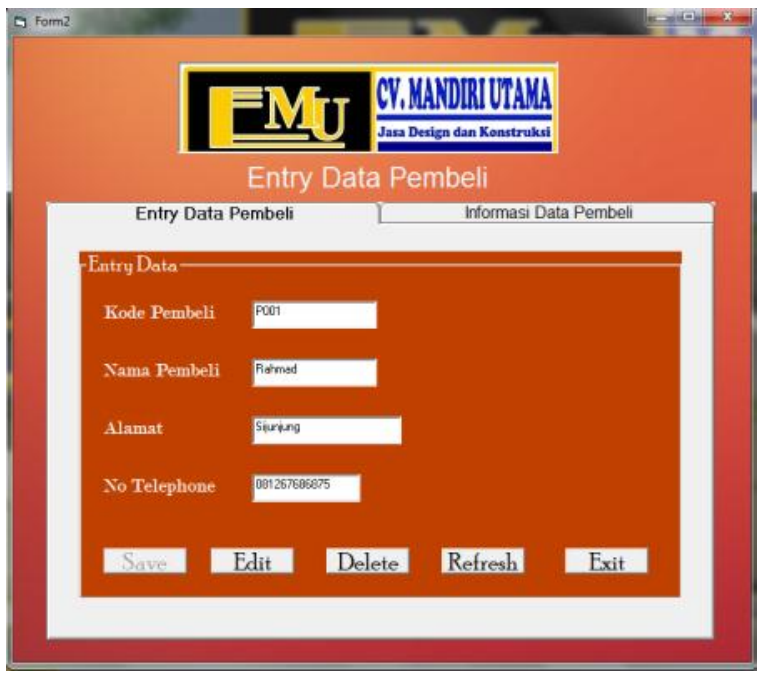

\section{Gambar 4.31 Form Entry Data Pembeli}

\section{Entry Data Pembelian}

Form entry data pembelian digunakan untuk mengentrikan data pembelian yang ada pada CV Mandiri Utama. Form entry data pembelian menyediakan kolom - kolom yang digunakan sebagai tempat melakukan entry data pembelian. Form entry data pembelian menyediakan beberapa proses yaitu proses penambahan data pembelian, proses pengubahan data pembelian, proses penghapusan data pembelian, dan proses pencarian data pembelian. Bentuk form entry data pembelian dapat dilihat pada gambar 4.32 berikut:

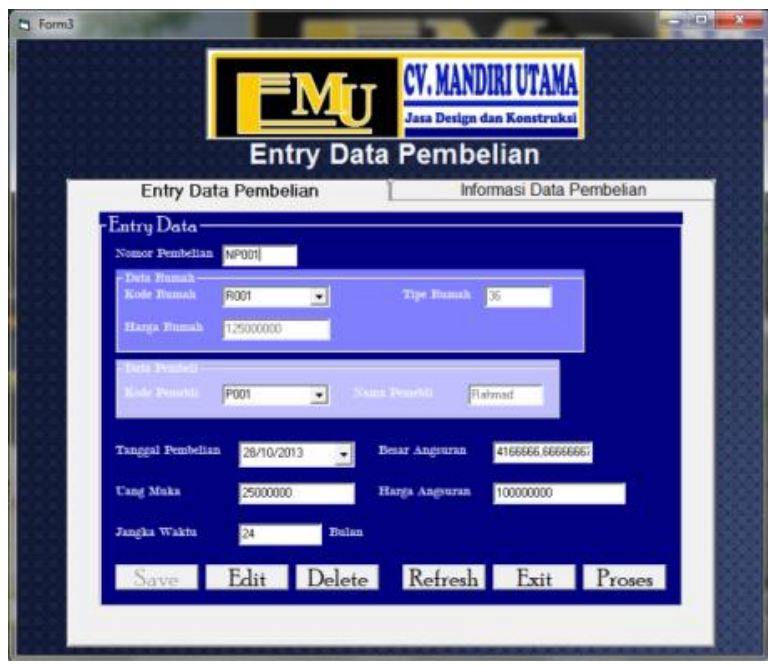

\section{Gambar 4.32 Form Entry Data Pembelian}

\section{Entry Data Angsuran}

Form entry data angsuran digunakan untuk mengentrikan data angsuran yang ada pada CV Mandiri Utama. Form entry data angsuran menyediakan kolom - kolom yang digunakan sebagai tempat melakukan entry data angsuran. Form entry data angsuran menyediakan beberapa proses yaitu proses penambahan data angsuran, proses pengubahan data angsuran, proses penghapusan data angsuran, dan proses pencarian data angsuran. Bentuk form entry data angsuran dapat dilihat pada gambar 4.33 berikut:

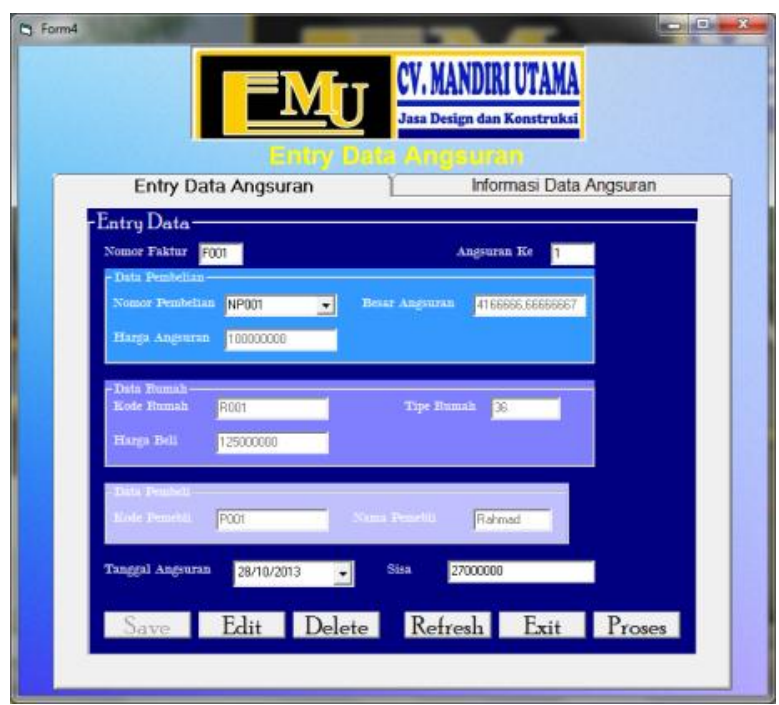

Gambar 4.33 Form Entry Data Angsuran 


\subsubsection{Program Laporan}

Terdapat 5 (lima) laporan, yaitu:

\section{Form Laporan Data Rumah}

Pada Laporan data rumah berisikan tentang data rumah dan berapa saja banyak unit rumah yang akan di bangun yang akan di jual kepada suplier pada CV Mandiri Utama. Bentuk form laporan data rumah dan laporan data rumah dapat dilihat pada gambar 4.35 berikut:

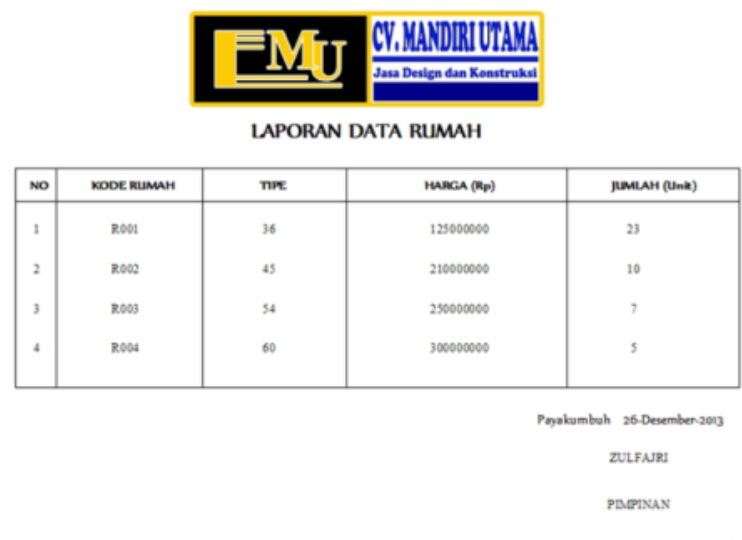

\section{Gambar 4.35 Laporan Data Rumah}

\section{Form Laporan Data Pembeli}

Laporan data pembeli berisikan semua tentang data pembeli perumahan pada CV Mandiri Utama. Bentuk form laporan data pembeli dan laporan data pembeli dapat dilihat pada gambar 4.37 berikut:

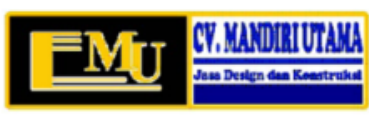

LAPORAN DATA PEMBEU

\begin{tabular}{|c|c|c|c|c|}
\hline no & KODE PEMEaru & Numu never & Nener menes & NOMON TELBON \\
\hline 1 & 2001 & $x \operatorname{sen} x$ & sipejoges & 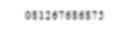 \\
\hline 2 & 2002 & Afrmatecis & Peguambat & 011344 \\
\hline 3 & 2003 & Speist Keede & oosen & 011383) \\
\hline - & 2004 & ratia Puat & Pax the & osyorsostas \\
\hline , & 2003 & 'othises iosta D? & Ltous 3 nizing & 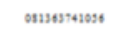 \\
\hline ' & 2008 & 'oty sogati & Tiater & องมางเงมามง \\
\hline , & 2007 & Oens Intit & Xoto cat atspen & 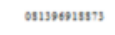 \\
\hline ' & 2000 & Domian yobeat & Limbases & 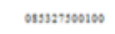 \\
\hline , & $p 00 \%$ & res Aets & Pae these & 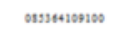 \\
\hline 10 & 2010 & Domisoents & Patarg Kanntis & onz1novos4s: \\
\hline
\end{tabular}

TELANA

\section{Form Laporan Data Pembelian}

Laporan Data Pembelian berisikan datadata proses pembelian rumah pada CV Mandiri Utama. Bentuk form laporan Data Pembelian dan laporan Data Pembelian dapat dilihat pada gambar 4.39 berikut:

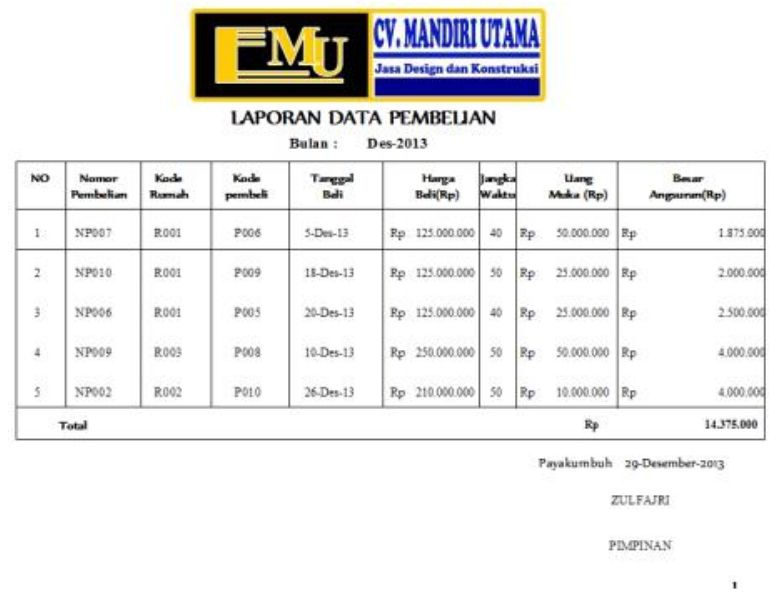

Gambar 4.39 Laporan Data Pembelian

\section{Form Laporan Data Angsuran Kredit} Rumah Perbulan

Laporan Data Angsuran Kredit Rumah Perbulan berisikan data-data proses data angsuran kredit rumah dalam satu bulan yang terjadi pada CV Mandiri Utama. Bentuk form laporan data angsuran kredit rumah perbulan dan laporan data angsuran kredit rumah perbulan dapat dilihat pada gambar 4.41 berikut:

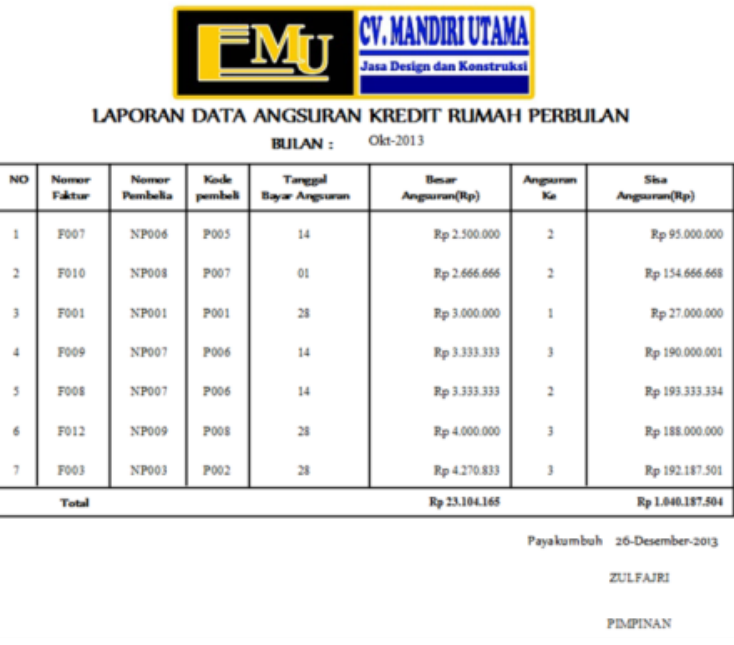

Gambar 4.41 Laporan Data Angsuran Kredit Rumah Perbulan

Gambar 4.37 Laporan Data Pembeli

$276 \quad$ Fakultas Teknik UMSB




\section{Form Laporan Data Angsuran Kredit Rumah Pertahun}

Laporan data angsuran kredit rumah pertahun berisikan data-data proses data angsuran kredit rumah dalam satu tahun yang terjadi pada CV Mandiri Utama. Bentuk form laporan data angsuran kredit rumah pertahun dan laporan data angsuran kredit rumah pertahun dapat dilihat pada gambar 4.43 berikut:

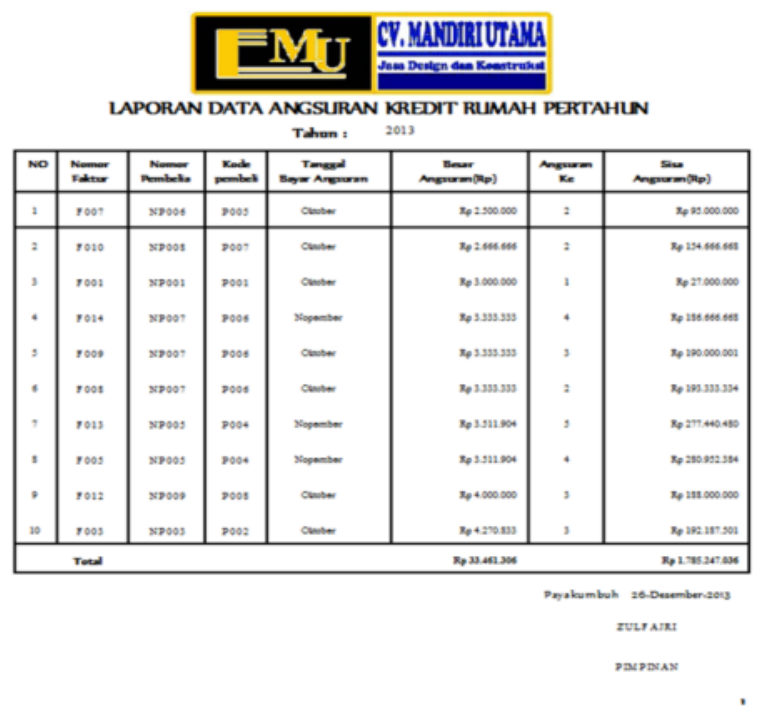

\section{Gambar 4.43 Laporan Data Angsuran Kredit Rumah Pertahun}

\section{PENUTUP}

\subsection{Simpulan}

Untuk meningkatkan sistem pengolahan data pembayaran perumahan pada CV Mandiri Utama perlu di perbaiki kekurangannya yang ada baik dalam penyajian data maupun dalam pencatatatan, penyimpanan data yang dapat meningkatkan mutu perusahaan dan mengurangi kesalahan dalam hal pencatatatan transaksi sehingga bisa dihasilkan suatu laporan yang akurat.

Dari analisa yang telah dilakukan penulis perumahan CV Mandiri Utama menghasilkan suatu kesimpulan yang dapat dikemukakan sebagai berikut :

1. Pengolahan data pembayaran perumahan pada CV Mandiri Utama masih dilakukan secara manual.

2. Sistem informasi dapat membantu CV Mandiri Utama untuk memproses data transaksi rumah dan angsuran pembayaran konsumen.
3. Sistem informasi dapat menyimpan data secara permanen sehingga memudahkan pencarian dan memudahkan dalam pengambilan keputusan.

\subsection{Saran-saran}

Perubahan sistem lama ke sistem baru tentu banyak menimbulkan kesulitan. Dimana para karyawan belum terbiasa menggunakan komputer dalam melakukan pencatatatan transaksi sampai pada pembuatan laporan keuangan. Untuk itu penerapan sistem yang baru tidak dapat dilakukan secara mendadak.

Sistem yang baru tidak sepenuhnya akan berhasil tanpa adanya penyesuaian dan pemeliharaan terhadap sistem yang akan diterapkan. Untuk menghindarkan kesulitan yang timbul nantiknya ada beberapa saran yaitu :

1. Sistem baru yang dikembangkan tidak selamanya sama dengan sistem yang lama. Untuk itu perlu adanya penyesuaian yang dilakukan antara sistem lama dengan sistem yang baru. Hal ini dilakukan untuk mengetahui kelemahan dari sistem baru sehingga kelemahan - kelemahan yang ada pada sistem yang baru dapat diperbaiki.

2. Penerapan sistem baru tidak dapat dilakukan secara mendadak, penerapan ini memerlukan penyesuaian dengan sistem yang lama agar aktivitas perumahan tidak terganggu.

3. Adanya training yang diberikan kepada karyawan yang akan menggunakan sistem baru sehingga mereka tidak canggung lagi dalam menggunakan komputer. 


\section{REFERENSI}

Deris, Rini. “ ". Data Flow Diagram.

(online).http://buset.staff.gunadarma.ac.id /Downloads/files/15824/DFD.pdf.

Diakses 11 Oktober 2013

Gunawan, Imam. 2011. Analisa Perancangan Sistem Informasi. (online) http://imamgunawan.files.wordpress.com/ 2011/03/handoutapsi2011.pptx. Diakses 11 Oktober 2013

Handika, Doni. "2008" . LANDASAN TEORI.(online) http://donihandika.files.w ordpress.com/2008/06/9-bab-ii.pdf.

Diakses 11 Oktober 2013

Hadi, Muhammad Zen." ". Database MySQL.(online) http://lecturer.eepisits.edu/ zenhadi/kuliah/.../Mysql.pdf. Diakses 11 Oktober 2013

HM, Jogiyanto. 2005. Analisa \& Desain. Yogyakarta : Andi Offset

HM, Jogiyanto. 2008. Sistem Teknologi Informasi. Yogyakarta : Andi Offset

Hariyadi, M. K. (2016). Pengembangan Sistem Pakar Berbasis Aturan Untuk Menentukan Mata Kuliah Yang Akan Diambil Ulang (Remedial) Dengan Metode Forward Chaining. Menara Ilmu, $X(64)$, 62-74. Retrieved from http://joernal.umsb.ac.id/index.php/menar ailmu/article/view/96

Sanjaya Ridwan. 2005. Membuat Мenu Cantik untuk Aplikasi Visual Basic 6.0. Yogyakarta : Andi Offset

Sutabri, Tata. 2005. Sistem Informasi Manajemen. Yogyakarta : Andi Offset

Wikipedia."__. MySQL. (online). http://id.wikipedia.org/wiki/MySQL.

Diakses 19 November 2013

Yung, Kok. 2005. Membangun Aplikasi Database dengan Visual Basic .Net 2005 dan Perintah SQL. Jakarta : PT Elex Media Komputindo 